\title{
YOUNG ADVENTURES IN ORCHID CONSERVATION
}

\author{
CAllum SwIFT \\ The Writhlington School Orchid Project, Writhlington School, Radstock, Bath, BA3 3NQ, England. U.K. \\ Scrumpy3700@hotmail.com
}

\begin{abstract}
RESUMEN. Esta conferencia decribe el trabajo empezado por un Colegio Británico único, que se ha concentrado intensamente en el campo de la conservación de las orquídeas para crear el Proyecto de Orquídeas del Colegio Writhlington. A través de la perspectiva de uno de los estudiantes con más experiencia en el proyecto, se analizan los resultados de los últimos siete años del proyecto, para ver como y porqué el proyecto ha alcanzado su situación actual. Se indican tambien las finalidades y objetivos futuros del proyecto. La conferencia subraya el enfoque del proyecto hacia una conservación efectiva en el Reino Unido y afuera, así como el envolucramiento de una comunidad tanto a nivel local como en una escala global. Se exploran también la experiencia educativa y el contexto curricular del proyecto.
\end{abstract}

KEY WORDS. Orchidaceae, conservation, threats, tropical research, micro-propagation, ex-situ conservation, science, enterprise.

\section{Introduction}

The Writhlington School Orchid Project has been described as a world leader in Orchid Conservation. Where Science, Enterprise and Conservation has been combined to a point where they are the future forerunners in conservation. Writhlington School is a state secondary school with 1200 pupils aged between 11 and 18. The Orchid project was project was started when an orchid grower donated a collection of hybrid Cymbidiums for the school greenhouses. These greenhouses were little used and dilapidated until they came into the management of Simon PughJones; the schools head of Physics. Simons Passion for orchids came from childhood inspiration from working at Keith Andrew Orchids, an orchid nursery in Dorset.

It has been in the last six years that 'The Project', as it is more commonly known, has established it self nationally and internationally. Presently we operate with a productive Orchid propagation laboratory. This has been constructed within one of the schools unused female toilets, which is highly practical in terms of the existing fixtures, and is now transformed into the hub of our conservation work. Internationally we work with groups in Guatemala, Sikkim (India), Laos and Costa Rica. And we now have developing partnerships in Gabon (Africa), Belize and Turkey. Nationally we work with a range of institutions and commercial organisations. Scientifically we work with RBG Kew, both with Orchid Taxonomist, Dr. David Roberts, and extensively with Kew's micro propagation department with the assistance of Grace Prendergast (fig. 1). Our entrepreneurial partners are The Eden Project, @ t Bristol, and Bicton Park Botanical Gardens. On the horticultural side we have numerous links with the Royal Horticultural Society (RHS).

WHEN I ARRIVED AT THE SCHOOL. I arrived at Writhlington School in September 2000, and instantly took to the extra curricular club known as 'the Greenhouse Club'. I have always had an active interest in Horticulture. Some of my earliest memories are

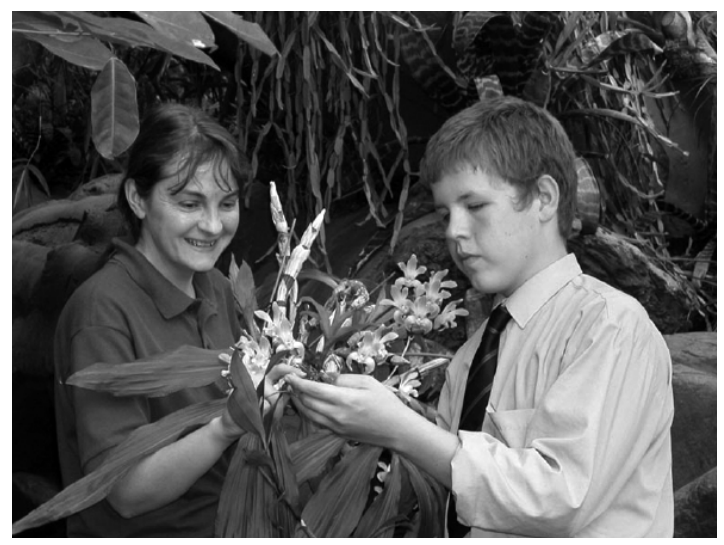

Figure 1. Callum, 13, working with at Bristol plant experts. 
of me in my Grandfather's greenhouse tending to the tomatoes that he grew. Generally this meant me eating them. After entering the school Greenhouse, I was bemused by these 'Orchids', with their strange looking flowers and even weirder names. The parts that particularly inspired and fascinated me about these unique plants were all extraordinary places they grew. I was immediately filled with visions of tropical rainforest, stretching from Brazil to Burma and Venezuela to Vietnam. I was instantly hooked, and pretty soon decided to make a career out of my favourite hobby. In the six years since arriving at the school I have been involved with almost all the branches of the project. I have constructed numerous prize winning displays at both local and national Orchid shows, spending many hours in the lab and I have produced research working with both botanical and scientific institutions.

Once I had joined the club I was immediately put in charge of the genera within the Oncidiinae family. After a few weeks I had learnt the basics of the family and how to grow these Oncidiums and Odontoglossums, I was able to tell visitors where they grew, what temperatures they prefer. And I was starting to get my tongue around pronouncing these ridiculous names, like Oncidium ornithorynchum and Osmoglossum pulchellum. After a few months I was allowed to make my first hybrid orchid, I selected two of my plants, and with the assistance of a match stick made the hybrid Colmanara Hawaii x Miltonia cuneata. I remained in charge of my section within the greenhouse for a total of five years, till they were eventually passed on to one of the younger members of the greenhouse club. Soon I relished that there was more to the orchids than just Miltonias, and eventually started to learn more and more about the other genera and tribes. I became particularly interested in Cymbidums, Dendrobiums, and Phragmipediums. Soon my obsession for orchid made its way into my home. I started growing orchids at home with just one hybrid Oncidium, but soon they began to dominate my bedroom. Currently I grow over 300 orchids within my house, ranging from small seedling species growing in my bedroom window sill, to the larger specimen plants which have made there habitat in my living room. I currently specialise in growing Phragmipedium.

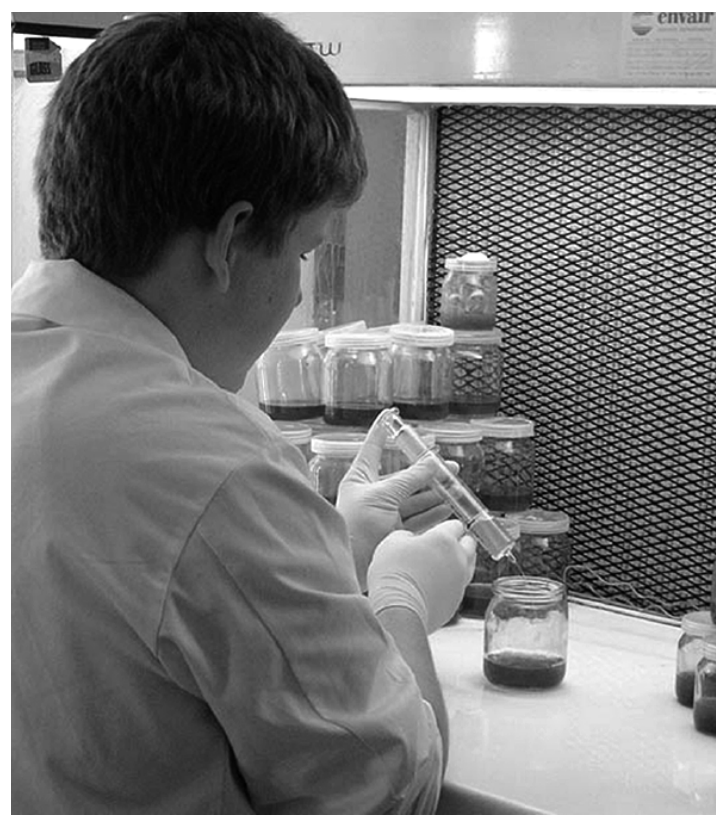

FIGURE 2. Working in a laminar air flow cabinet.

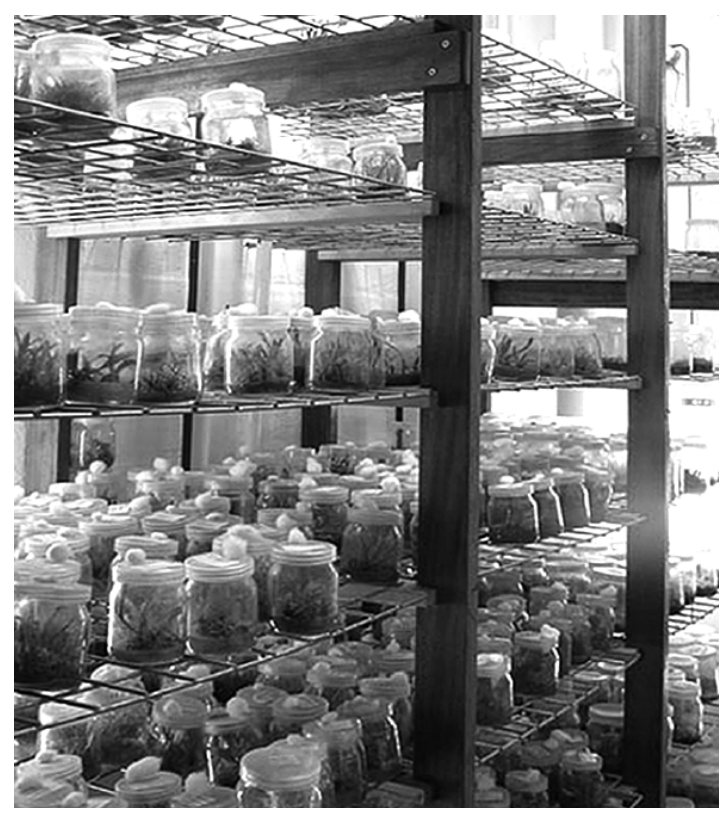

FIGURE 3. Writhlington school propagation lab.

It was after the construction of the orchid lab at the school, that the project really begin to take off. We received our first laminar air flow cabinet (fig. 2, 3) from the Bristol eye hospital and seed sowing began. Soon we were donated a further three airflows from the RBG Kew micro propagation department, and we were able to convert the schools disused female toilets into a 
fully functioning propagation lab. It was in the year of 2004 that I took over the day to day running of the propagation lab, and I awarded myself the grand title of Lab manager. After three years of trial and error, the project had one of Britain's largest Orchid specialist propagation labs in terms of number of orchids sold annually.

In the year of 2005 I was lucky enough to be including on two tropical rainforest research trips. In August I travelled as part of a group of four to the Peten region of Guatemala (fig. 4). We were working with a group of Orchid Conservationists known as Yaxhà Orchids. On this expedition we were faced with Crocodiles, Mayan Architecture, and also the painful end of a swarm of tropical hornets. With the assistance of Federico Fahsen we spend two weeks in primary seasonally dry rainforest, conducting vital research on orchid diversity over the reserve. This work was eventually published, and display at the RHS London Orchid Show where it receive a RHS Gold medal (fig. 5). And it was also presented at the 'Young Scientist of the Year' competition, hosted by the Royal Society. I have also spent two weeks working in the Mata Atlantic rainforest, working with the Rio Atlantic trust (fig. 6). I used this expedition as a chance to test my theory on orchid diversity, developed while in Guatemala.

After returning from my first expedition I was approached to give a lecture to a local gardening society. Since then I travelled across the country lecturing to enthusiast, gardeners, and orchid fanciers. This has given me a chance to both improved my self confidence and allowed me a chance to deliver the message of the Writhlington School Orchid Project.

The Development of the Orchid starter Kit. One of the key turning points in the success of the Writhlington School orchid project has been the development of our unique product, known as the Orchid Seedling conservation kit(fig. 7). Initially invented by the 2003 Young Enterprise Company, Stem Labs, the kits has gone through serious changes to become the projects largest selling product; with sale reaching over $£ 8,000$ a year. The Kit consists of a seedling orchid, growing in-vitro on a nutrient agar jelly, a pot and potting media, for growing the orchid. We have also developed instructions for effective growth of the seedling orchid, and offer free advice through our website.

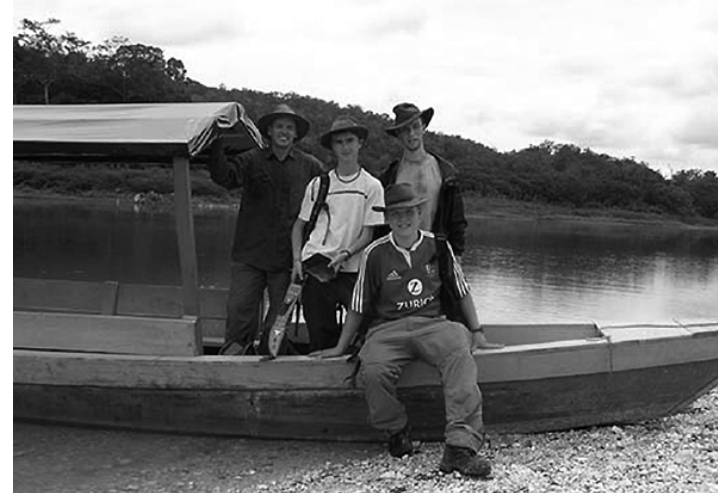

FIgURE 4. August 2005 expedition team to Guatemala, shores of Laguna Yaxhà.

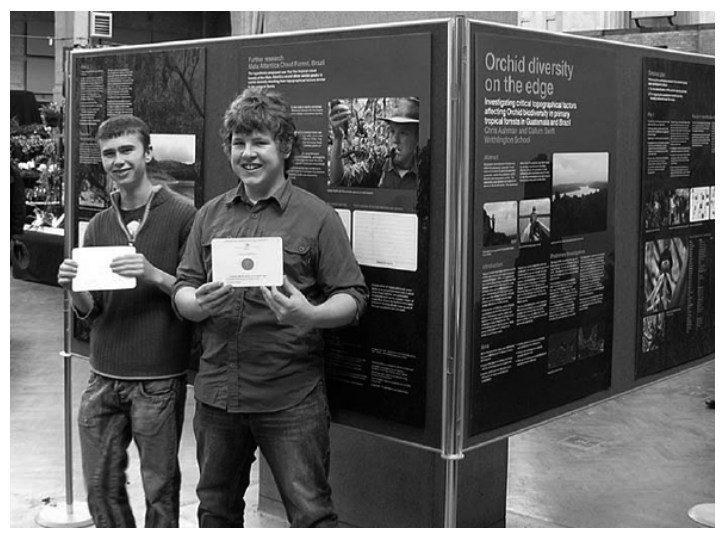

FIGURE 5. 2006 London Orchid show, RHS Gold medal.

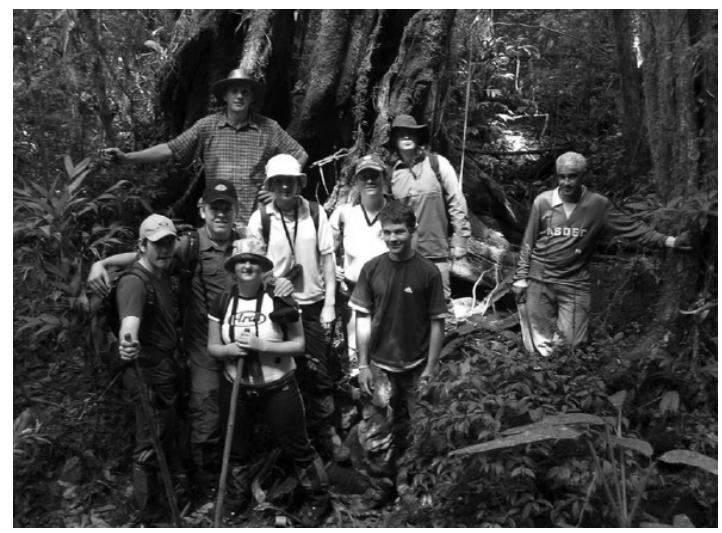

FiguRE 6. October 2005 expedition team to Brazil.

Currently we make the majority of our sales through the whole sale market (fig. 8). We sell through The Eden Project, Bicton Park Botanical Gardens@t Bristol, Hillier's Garden Centres, and we have a provisional agreement to sell our kits through 


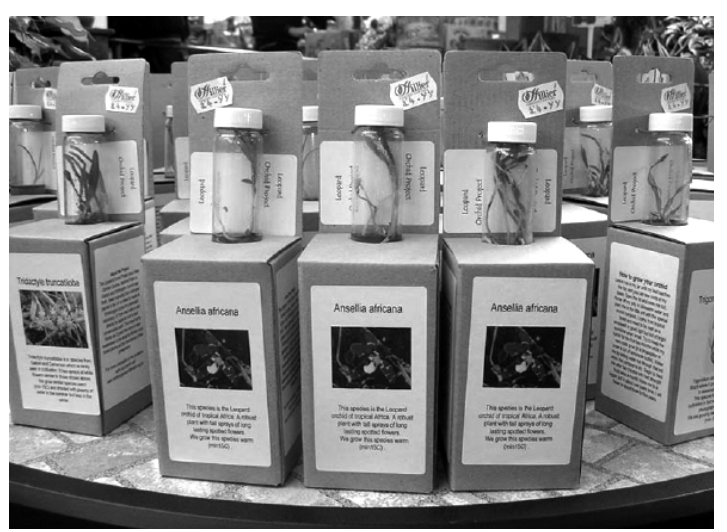

FIGURE 7. Orchid seedling conservation kit.

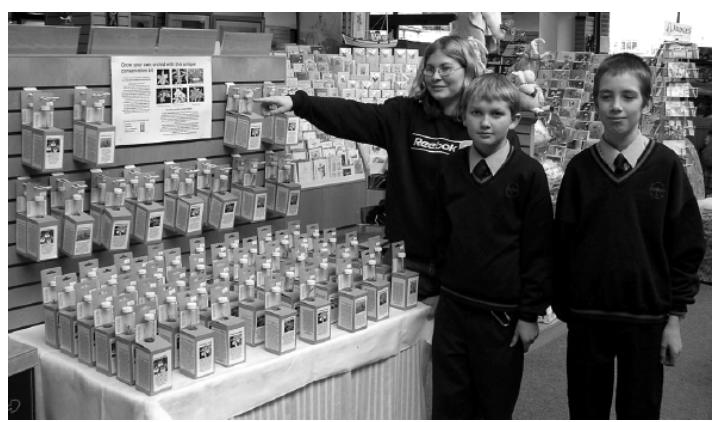

Figure 8. Sales area of orchid seedlings in Bicton Park Botanical gardens.

the Kew shop. The kits are individually branded to the organisation that they are distributed to, and $£ 1$ from every kit sold is sent back to the community that we work with.

\section{Our Methods of Conservation}

After seven years we can identify some key ways in which effective conservation can be introduced and maintained. These point have been identified as,

- Working with the local community

- Identifying flagship species

- Our media appeal

- Our links to specialists

- Our unique position

- Ability to be self sustaining

- Counterpart organisations

- Provide real rewards

I will consider each of these in turn.

WORKING WITH A LOCAL COMMUNITY. In each of the countries that we work, we try to link our scientific expedition with a local school. By doing this we can help in educate the community, raising the issues of conservation, and demanding its significance. We aim to link each school to a counterpart organisation in the U.K. setting a positive agenda for the future

Identifying Flagship Species. Through identifying a flagship species, which can either be a well known cultivated species, such as Prosthechea cochleata, or a completely new species, we can centre each project on the sale and conservation of these flagships. We try to identify orchids which are both visually attractive to a buying customer, but must also have an interest factor about it; such as unique characteristics. Examples include our flagship in Sikkim, Cymbidium whiteae, which is endemic to the mountains surrounding Gantok. Some people estimate that there are less than fifty of these plants left growing in the wild. We have raised many thousands of these seedlings in our lab and will take them back to Gantok for distribution to locals, relieving pressure of the illegally collected plants and involving local gardeners in the conservational loop. We found seed of this orchid from a cultivated plant in the U.K.

Our Media APPEAl. Because we are a school, the media has taken to the project extremely well. This has enabled us to advertise what we do for free. This means that nationally we are well known in both the Orchid community, as well as with the non enthusiasts. We have appeared in on both television, and in the newspapers. By getting the nation behind us, from coverage such as the RHS Chelsea flower show, we can increase sales and support for orchid conservation.

SPeCialist LinKs. Over the last six years we have made links with countries and organisation that no other school project has been able to do before. Our students communicate with world experts in other countries about there individual research. We have links with botanical gardens, universities, and scientists globally.

UNIQUE POSITION. We are in a unique position; because we are a school. With our position at the heart of the local community and our army of young volunteers we have the opportunity to do things that are not possible for many conservation groups. Each of the students 
involved are able to complete up to $50 \%$ of there science coursework based around the orchid project and can enter into careers in Horticulture, Botany and Ecology. Students take part in expeditions to tropical forest gaining personal skills and broadening the knowledge base of the project.

Ability to BeCome Self Sustaining. Because we are a Business and Enterprise specialist school we are able to fund all our work in tropical countries through the sale of the products from companies within the school, run by the students. Through programs such as Young Enterprise we have been placed in a position where we are almost completely self funding. It also gives our students a real chance to see how business works, whilst gaining real rewards such as places on our expeditions. In 2006 Writhlington was awarded 'Enterprise school of the year'

COUNTERPART ORGANISATIONS AND PROVIDING REAL REWARDS. With each tropical country and community we work with, we try to link it with a counterpart organisation in Britain. For we have example linked Yaxhà Orchids in Guatemala to the Bicton Park Botanical gardens in Devon. The idea being that funds raised from U.K. sale of our orchid starter kits can be sent out to support work in Guatemala. Bicton Parks gains through information and links with Yaxhà.

\section{What is the future of the Writhlington School Orchid Project?}

Currently we see a number of routes for the future of the project. Ideally we hope to continue our current trend with work in tropical countries. We hope that our orchid conservation kits will continue to sell with the popularity that they have today, and will continue to fund all our work with orchid research. It is also hoped that with the development of a new school at Writhlington, planned for September 2010, our decrepit greenhouse can be replaced with a state of the art visitor centre and educational growing area. And we also hope to go on with developing new links, as well as maintaining existing ones. At the moment we have a number of both established and developing links with partners in tropical regions.

Paksong Orchid Project. We are currently work- ing in Laos to find a way to protect the native orchids from the Chinese medicine trade, and also the Thai cut flower market. We are working with the community in Paksong to identify potential objectives for effective conservation and rural development. Our plan is to relieve pressure on threatened wild populations by encouraging coffee farmers to grow orchids on and under their coffee trees. These orchids will be raised from seed in a new Lab in Paksong. As well as supplying the existing markets with sustainable crops, it will provide the low income coffee farmers with a second crop. Local orchid species under threat include Dendrobium compactum, which is illegally harvested by the tonne, and is exported to China.

Gabon Orchid Project. This project was launched earlier this year, and aims to fund the employment of staff for the Monte Crystal National park. We will be selling orchids such Ansellia africana through the Hiller chain of garden centres. We are also working with school iniatives in South Africa.

The Orchid Ice Cream Project. Working as part of a committee, with the RHS, the Eden Project and Turkish partners, we are operating to find horticultural solutions to the unsustainable collection of terrestrial orchid tubers in Turkey (fig. 9). These tubers are boiled, dried, and then ground up to make a powder known as salep; which is used to flavour ice cream, also known as Dondurma.

What are the lessons that can others learn from the

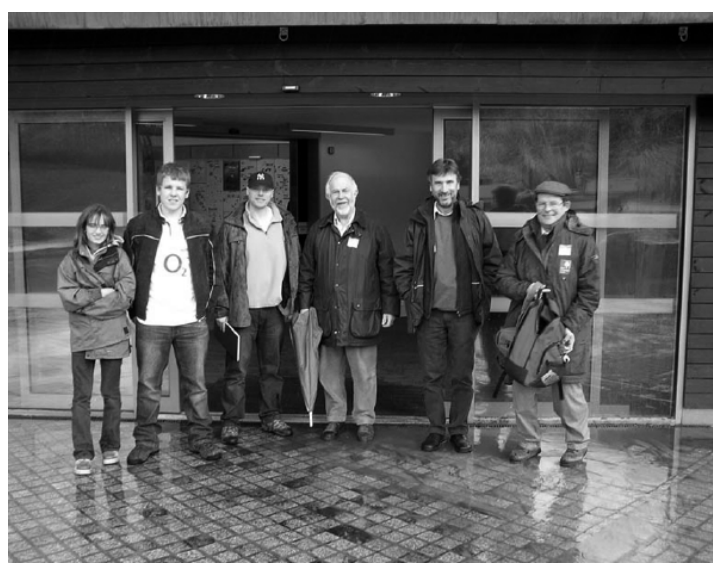

FIGURE 9. Committee of the Turkish orchid ice cream project. 
Writhlington Experience? We have identified the key points for success to be:

- Aiming high

- Making links

We have demonstrated that an ordinary state school can have a major impact in conservation while delivering quality educational experiences, but for this to happen the support of our partner organisation has been essential.

Oh, and by the way all this has been great fun for me and at 17 years old I feel ready for an exiting career in plants and conservation.
ACKNOWLEDGMENTS. I would like to thank Simon for giving me this chance to do something worth while at school. With out all the opportunities the project given me, I wouldn't be in the position that I am in today. I would also like to thank him for putting up with me on all our expeditions. I would also like to thank the Stanley Smith horticulture trust for sponsoring me to attend this conference. Without there generous support I would never have been able to make this trip. I would like to show appreciation to the staff at Writhlington School for giving me the time off school, so that I could attend this conference. And for allowing me so many days of school over the last six years to allow me to work with the orchids.

Callum Swift is a sixth form student currently studying his A-levels at Writhlington Business \& Enterprise specialist school, England. He has been involved with the Writhlington School Orchid Project for over six Years, and has plans for further work in orchid conservation after studying a Botany degree at University. He has extensive experience in the field of orchid conservation, and has work with experts from RBG Kew, and the Eden project; and has played a key role in the development of the micro propagation department within the Writhlington School Orchid project. 